УДК 378.091“20”

DOI: $10.15330 /$ esu. 15.17-25
Наталія Бахмат,

доктор педагогічних наук, професор,

Кам'янець-Подільський національний університет імені Івана Огіснка

(м. Кам'янець-Подільський, Україна)

Nataliia Bakhmat,

Doctor of pedagogic sciences, Professor,

Kamianets-Podilskyi Ivan Ohiienko National

University (Kamyanets-Podilskyi, Ukraine)

bahger.teacher@gmail.com

\section{Людмила Сидорук,}

аспірант, Кам'янець-Подільський національний університет імені Івана Огіснка,

викладач, Подільський спеціальний навчальнореабілітаційний соціально-економічний коледж (м. Кам'янець-Подільський, Україна)

\section{Liudmyla Sydoruk,}

Post-graduate student, Kamianets-Podilskyi Ivan Ohiienko National University;

teacher, Podilia educational and rehabilitational

caollege of social sciences and economics

(Kamyanets-Podilskyi, Ukraine)

lsudoryk@ukr.net

\title{
ФОРМУВАННЯ СУЧАСНИХ УЯВЛЕНЬ ПРО АДАПТИВНЕ ОСВІТНЕ СЕРЕДОВИЩЕ ЗАКЛАДУ ВИЩОЇ ОСВІТИ
}

\section{DEVELOPMENT OF CONTEMPORARY VISIONS ABOUT ADAPTIVE EDUCATIONAL CIRCUMSTANCES OF THE HIGHER EDUCATIONAL ESTABLISHMENT}

У статті обгрунтовано необхідність формування адаптивного освітнього середовища закладу вищої освіти. На основі аналізу наукових прачь охарактеризовано сутність поняття “адаптивне освітне середовище закладу вищої освіти”. Визначено його основні характеристики і умови формування, розглянуто окремі аспекти реалізачії.

Ключові слова: адаптачія освітнього прочесу, освітнс середовице, інклюзія, адаптивне навчання, інформаційно-комунікаційні технології, вища освіта.

The article emphasizes the necessity of adaptive educational circumstance formation in the higher educational establishment, such surroundings should be adjusted to learners' skills, needs, and abilities in order to make these students to be active participants of educational process and provide the right for a high quality education.

Taking into consideration the definition given by foreign and Ukrainian scholars, adaptivity of educational process is considered to use IT technologies or disabled learnercentered teaching with a deep concern of their psychological and physiological features. The scholars announce main characteristics of adaptive educational circumstances to be flexibility of education and focus on individual features of students.

It was proved that formation of adaptive educational circumstances should be created by means of integrating of pedagogical, digital and inchusive technologies which take into essential consideration learners' individual skills and needs. Adaptive teaching will provide flexibility and personalization for students to have the equal access to higher education.

The research resulted the idea about importance of adaptivity in formation of educational circumstances which match the criteria of society and educational principles. Realization of these peculiarities of education would be possible through usage of IT technologies in this way there will be necessary circumstances for individualization and personalization of teaching. 
There are outlined advantages of adaptive teaching with using IT technologies for students. Зокрема, визначено, що ї застосування дозволяе підвищити якість навчання й підсилити освітні ефекти впровадження інновачійних педагогічних програм і методик, оскільки дає викладачам додаткові можливості для побудови індивідуальних освітніх траєкторій здобувачів вицої освіти, а також дозволяе автоматизувати чей процес.

Key words: adaptation of educational process, educational circumstances, inclusion, adaptive teaching, digital and communicative technologies, higher education.

Гуманізація та демократизація суспільства в Україні зумовила зміни в ставленні до проблем освіти осіб 3 обмеженими фізичними можливостями. Основою інтеграційних процесів у закладах вищої освіти (ЗВО) є продовження традицій попереднього освітнього рівня, проте професійна підготовка має низку особливостей, пов'язаних з необхідністю адаптації учасників освітнього процесу до навчання в умовах інклюзії та один до одного. Специфіка педагогічної роботи зі студентами, які мають особливості психофізичного розвитку (порушення слуху, зору, опорно-рухового апарату тощо) та здоровими здобувачами вищої освіти, полягає в тому, що вона проводиться одночасно, проте вимагає різних підходів, форм, методів і засобів, які враховують індивідуальність кожного 3 них. Це зумовлює необхідність переходу від традиційної стратегії управління пізнавальною діяльністю студентів до більш гнучкої, здатної підлаштовуватися до їх особистісних чинників і створювати умови для їх продуктивної діяльності.

Нагальна потреба в оріснтації системи освіти на особистість здобувача вищої освіти вимагає проектування моделі нового освітнього середовища 3ВО, здатного адаптуватися до їх здібностей, потреб і можливостей, зробити їх активними учасниками освітнього процесу та забезпечити права всіх громадян на здобуття якісної освіти. Формування адаптивного освітнього середовища дозволить ЗВО вийти на якісно новий рівень підготовки фахівців. Тому на сучасному етапі актуальним $є$ дослідження адаптивного освітнього середовища, на основі аналізу концептуальних підходів до його трактування.

Особливості формування освітнього простору для осіб 3 обмеженими можливостями здоров'я, застосування особистісно орієнтованих методів навчання, 3 урахуванням індивідуальних особливостей їх навчально-пізнавальної діяльності знайшли відображення в роботах українських дослідників С. Місяк, Т. Носової, С. Савченко, О. Поляк, О. Царькової та ін. Питання, пов'язані з інклюзією в системі вищої освіти України, висвітлені в наукових працях В. Бондаря, І. Іванової, І. Калініченко, А. Колупаєвої, К. Кольченко, Г. Нікуліної, Л. Сердюк, П. Таланчука.

Адаптивне навчальне середовище як модель надання інклюзивних освітніх послуг розглядають М. Захарчук, Н. Данакін, А. Шутенко. Адаптивна освітня система, яка здатна забезпечити досягнення практично кожним учнем оптимального рівня інтелектуального розвитку відповідно до його природних задатків і здібностей, є предметом дослідження вчених Т. Давиденко, Н. Капустіна, Т. Шамової, Є. Ямбурга та ін.

Тенденції розгляду поняття “адаптивність" у межах освітнього процесу зустрічаються в працях сучасних дослідників В. Бондаря (специфіка сучасної адаптивної вищої освіти), В. Пішванової (принципи адаптативного навчання), С. Прийми (особливості функціонування інтелектуальних адаптивних навчальних систем), П. Федорука (адаптивні системи індивідуального дистанційного навчання на засадах новітніх Web-технологій) та ін. 
Питанням впровадження в освітній простір сучасних інформаційнокомунікаційних технологій, застосування хмарних технологій, професійної підготовки майбутніх учителів в умовах інформатизації освіти присвячено наукові розвідки Н. Бахмат, В. Бикова, Л. Карташової, . Спіріна, М. Шишкіної, В. Лапінського та ін.

Слід зазначити, що адаптивне освітнє середовище ЗВО в умовах інклюзії не стало предметом грунтовного наукового аналізу. Дослідження не в повній мірі дають завершене цілісне уявлення про адаптивне освітнє середовище ЗВО в умовах інклюзії. Визначена проблема залишається актуальною через неоднозначність i суперечність наукових аспектів, що стосуються визначення змісту досліджуваного поняття.

Метою статті $є$ уточнення сутності адаптивного освітнього середовища та з'ясування його основних характеристик на основі аналізу існуючих підходів до тлумачення цього поняття вітчизняними та зарубіжними науковцями.

Для визначення особливостей адаптивного освітнього середовища ЗВО вважасмо за необхідне детально розглянути поняття "середовище" та "освітнс середовище".

У тлумачному словнику наведено таке пояснення поняття “середовище": оточення, сукупність природних і соціально-побутових умов, а також сукупність людей, пов'язаних спільністю цих умов, в яких протікає діяльність людського суспільства, організмів [14].

Термін “середовище” в педагогіці з'явився в епоху Просвітництва, а у вітчизняній педагогіці та психології - в минулому столітті, коли почали вживатися поняття "педагогіка середовища" (С. Шацький), “середовище колективу" (Л. Новікова), "навколишнє середовище" (А. Макаренко).

Освітнє середовище вивчали як зарубіжні (Дж. Гібсон, У. Мейс, Т. Менг, М. Турвей, В. Ясвін та інші), так і вітчизняні дослідники (Г. Балл, І. Бех, Є. Бондаревська, С. Максимова, О. Пєхота, В. Рибалка, В. Семиченко, В. Сєріков, С. Сисоєва та інші). Аналіз педагогічної літератури демонструє, що підходи до визначення освітнього середовища змінювалися. Науковці не лише по-різному трактують зміст поняття "освітнє середовище", а й мають відмінні погляди на його структуру та функції.

На основі аналізу ідей Я. Коменського, Л. Корчака, А. Макаренка, Г. Спенсера та інших педагогів Л. Макар зазначає, що під терміном "освітнє середовище" у педагогіці розуміється сукупність умов, котрі впливають на формування i функціонування людини в суспільстві, на наочну i людську обстановку особистості, її здібностей, потреб, інтересів, свідомості [10, с. 233].

Дослідники Б. Боденко, А. Куракін, Ю. Мануйлов, А. Хуторський під освітнім середовищем розуміють природне та штучно створене соціокультурне оточення людини, що включас зміст і різні види засобів освіти, здатні забезпечувати продуктивну діяльність студента, слухача, управляючи процесом розвитку особистості за допомогою створення сприятливих для цього умов [10, с. 235].

Вітчизняні та зарубіжні науковці й практики трактують освітне середовище, як частину життєвого, соціального середовища людини, яка виявляється у сукупності усіх освітніх факторів, що безпосередньо або опосередковано впливають на особистість у процесах навчання, виховання та розвитку; $\epsilon$ певним виховним простором, в якому здійснюється розвиток особистості $[17$, с. 9$]$. 
У наукових психолого-педагогічних працях дослідники при розгляді освітнього середовища $з$ точки зору наявності умов для засвоєнння системи знань, з урахуваннням індивідуальних особливостей, внутрішніх ресурсів та можливостей особистості вживають поняття "адаптивне освітнє середовище".

У словнику іншомовних слів адаптивний (англ. adaptive, від лат. Adapto пристосовую) означає пристосовний. У тлумачному словнику української мови значення адаптивний також трактується як здатний пристосовуватися. В контексті освітнього середовища ЗВО адаптивність у вузькому розумінні передбачає його здатність пристосовуватися до різних умов і змін. Базуючись на такому розумінні адаптивності освітнє середовище в першу чергу має відображати потреби суб'єктів освітнього процесу.

На думку П. Третьякова адаптивне освітнє середовище - це соцальнопедагогічна система, що здатна пристосовуватися до змін зовнішнього середовища, яка намагається, 3 одного боку, максимально адаптуватися до особистості 3 ii індивідуальними особливостями, а $з$ іншого - гнучко реагувати на власні соціокультурні зміни [15, с. 9].

Білоруський вчений С. Гайдукевич теоретично обгрунтував необхідність адаптації освітннього середовища, яке би сприяло особистісному розвитку та вирішувало проблему соціалізації, для дітей 3 особливостями психофізичного розвитку. Він розробив практичні рекомендації щодо проектування, моделювання й організації в закладах освіти безбар'єрних адаптивних освітніх середовищ [12].

Дослідниця Ю. Кислякова розглядає адаптивне освітнє середовище як систему умов (архітектурне безбар'єрне середовище, технології, методи, засоби навчанння тощо) і взаємин (інклюзивна культура), що створюється в закладі освіти та максимально забезпечує можливості для задоволення особливих освітніх потреб. Вона описує особливості створення адаптивного освітнього середовища в умовах інклюзіі, яке через свій зміст i властивості впливає на всебічний розвиток особистості [7, с. 118].

Визначаючи концептуальні підходи до впровадження інклюзивної освіти у ЗВО науковці К. Кольченко та Г. Нікуліна, вказують на те, що формування інклюзивного освітнього середовища для студентів 3 інвалідністю відбувається шляхом запровадження комплексної системи супроводу навчання, забезпечення архітектурної, інформаційної та соціальної безбар'єрності освітнього середовища, створення матеріально-технічної бази, адаптованої до потреб студентів, підвищення їхньої мобільності [9].

Учена Т. Бондар характеризує інклюзивне освітнє середовище як сукупність умов, що забезпечують рівний доступ особам з особливими потребами до якісної інклюзивної освіти в інклюзивному навчальному закладі незалежно від їх психофізичного розвитку, стану здоров'я, віку, статі, соціально-економічного статусу, раси, місця проживання і виховання, та як сукупність учасників освітнього процесу, пов'язаних спільністю умов, у яких відбувається їхня діяльність [2, с. 22].

На думку А. Колупаєвої, Ю. Найди, Н. Софій, формування інклюзивного середовища орієнтоване на розвиток особистості та відповідність запитам соціального оточення і сподіванням людини. Науковці виділяють такі ознаки інклюзивного освітнього середовища: спланований та організований фізичний простір, сприятливий соціальний та емоційний клімат; наявність умов для спільної роботи здобувачів освіти та надання один одному допомоги в досягненні позитивного результату [8]. 
У Законі України "Про освіту" інклюзивне освітнє середовище трактується як “сукупність умов, способів і засобів їх реалізації для спільного навчання, виховання та розвитку здобувачів освіти 3 урахуванням їхніх потреб та можливостей” [4].

Інклюзія, у широкому розумінні, передбачас створення рівних можливостей для всіх здобувачів освіти, проте більшість дослідників акцентують увагу саме на індивідуальних особливостях осіб з обмеженими фізичними можливостями.

Науковець М. Чайковський указує на те, що методи викладання, які $\epsilon$ ефективними для навчання студентів $з$ особливими потребами, приносять користь усім студентам, а методи, що не відповідають потребам людей 3 інвалідністю створюють такі ж самі, хоча й часто латентні, бар'єри в освіті здорових людей $[18$, c. 84].

Однією $з$ форм навчання й інтеграції в соціум осіб, що мають порушення здоров'я Д. Бояринов вважає дистанційне навчання на базі нових інформаційних технологій. Він розглядає адаптивне освітнє середовище як інформаційну систему, побудовану з використаннням сучасних інформаційних технологій, які створюють умови рівного доступу до якісної освіти, забезпечують гнучкість та індивідуалізацію процесу навчання [3].

Адаптувати навчальний процес відповідно до здібностей здобувачів вищої освіти, на думку В. Пішванової, дозволяє комп'ютерно-орієнтоване освітнє середовище. Вона виділяє наступні принципи адаптивного навчання: індивідуалізація освітніх потреб; побудова індивідуальних освітніх стратегій; $\square$ психологічне коригування стереотипів мислення й діяльності особистості; розробка адаптивного управління інноваційними моделями організації навчання [13, с. 181-182]. Загальною основою для всіх вищезазначених принципів $\epsilon$ індивідуалізація мислення та механізми самореалізації особистості.

Одним 3 основних способів індивідуалізації $\epsilon$ побудова індивідуальних траєкторій навчання, що передбачає підбір змісту навчального матеріалу, послідовності та темпу його засвоєнння відповідно до освітніх потреб і можливостей студентів. При цьому важливою проблемою $є$ вибір оптимальної послідовності вивчення теоретичного матеріалу та закріплення його за допомогою спеціально підібраного набору навчальних завдань. Ї̈ можна вирішити за допомогою систем електронного навчання, які дозволяють представити теоретичний матеріал в текстовому, аудіо та відеоформаті, відповідно до рівня знань здобувача вищої освіти, оцінити засвоєння матеріалу.

Адаптивні системи навчання, що дають змогу забезпечити диференціацію та персоніфікацію освітнього процесу на високому якісному рівні, перебувають на стадії експерементального вивчення та лише починають впроваджуватися.

Учений П. Федорук обгрунтовує необхідність створення адаптивної системи дистанційного навчання та контролю знань на базі інтелектуальних інтернеттехнологій. У своєму дослідженні він доводить, що застосування сучасних інформаційних технологій в освітньому процесі дозволяє підвищити якість навчання й підсилити освітні ефекти від застосування інноваційних педагогічних програм і методик, оскільки дає викладачам додаткові можливості для побудови індивідуальних освітніх траєкторій студентів, а також дозволяє автоматизувати цей процес [16, с. 3-4]. 
Адаптивна система навчання з використанням інформаційних технологій має низку переваг як для викладачів, так і для студентів, які наведено в таблиці 1 $[11$, c. 75$]$.

Таблицяя 1.

\section{Переваги адаптивної системи навчання}

\begin{tabular}{|c|c|}
\hline Для викладача & Для студентів \\
\hline $\begin{array}{l}\text { Можливість постійного вдосконалення } \\
\text { навчальних курсів на основі глибокого } \\
\text { аналізу навчального прогресу, особливос- } \\
\text { тей проходження індивідуальної траєкторії } \\
\text { кожним студентом, що сприяє покращенню } \\
\text { якості освітньої діяльності закладу загалом. }\end{array}$ & $\begin{array}{l}\text { Індивідуалізація освітнього процесу, що } \\
\text { дозволяє досягнути } \\
\text { результату незалежно від початкового рівня } \\
\text { знань, здібностей, } \\
\text { психофізичного розвитку тощо. }\end{array}$ \\
\hline $\begin{array}{l}\text { Можливість відслідковування навчального } \\
\text { прогресу студента та корегування його в } \\
\text { paзi необхідності. }\end{array}$ & $\begin{array}{l}\text { Можливості вільного вибору власної } \\
\text { траєкторії навчання в процесі } \\
\text { знань. }\end{array}$ \\
\hline \begin{tabular}{lllr} 
Можливість & \multicolumn{2}{l}{ отримання даних } \\
iндивідуальні & освітні потреби кожного \\
студента. & & &
\end{tabular} & $\begin{array}{l}\text { Можливість здійснювати } е \text { самоаналіз, } \\
\text { відслідковувати власний освітній маршрут, } \\
\text { прогрес у процесі навчання за рахунок } \\
\text { зворотного зв'язку від системи в режимі } \\
\text { реального часу. }\end{array}$ \\
\hline $\begin{array}{l}\text { Автоматизація оцінювання та прогно- } \\
\text { зування, що значно підвищує ефективність } \\
\text { цих процесів. }\end{array}$ & $\begin{array}{l}\text { Регулювання ступеня складності навчаль- } \\
\text { ного контенту, що сприяє більш ефектив- } \\
\text { ному, послідовному проходженню курсу. }\end{array}$ \\
\hline $\begin{array}{lc}\text { Можливість } & \text { зниження } \\
\text { навантаження, } & \text { вивільнення } \\
\text { професійного розвитку чи ін. }\end{array}$ & $\begin{array}{l}\text { Заохочення до саморозвитку і реалізації } \\
\text { індивідуальної } \text { освітньої } \\
\text { незалежно від викладача, за допо допогою } \\
\text { автоматизованих циклів зворотного зв'язку. }\end{array}$ \\
\hline
\end{tabular}

Науковці Н. Бахмат, Л. Карташова, І. Пліш вказують на те, що першочерговість гуманістичності педагогічних технологій і спрямованість на особистісні якості та можливості, зумовлюють необхідність створення інформаційноосвітнього електронного середовища закладу освіти [6, с. 196]. Проектування та формування електронних середовищ стає можливим за рахунок електронних освітніх ресурсів (ЕОР). Дослідниця Л. Карташова визначає особливості діючої моделі інноваційного відкритого електронного освітнього ресурсу ACCENT, який пропонує до використання як електронної освітньої платформи. Перевагами цього відкритого мережевого ресурсу $\epsilon$ те, що він $\epsilon$ доступним для всіх учасників освітнього процесу і забезпечує умови для обміну досвідом та співпраці [5, с. 3].

Аналізуючи проблеми впровадження інформаційно-комунікаційних технологій (ІКТ), учені В. Биков, О. Спірін, О. Пінчук вважають, що пріоритетами при побудові інформаційно-освітнього середовища мають бути: широке використання в освітньому процесі комп'ютерно орієнтованих засобів та IКТ навчання, практичне впровадження технологій дистанційного навчання, забезпечення IKT підтримки науково-дослідної роботи, широке впровадження ІКТ в управлінні освітою на різних рівнях, у різних галузях, для всіх типів навчальних закладів. Дослідники виокремлюють технологічні принципи побудови інформаційно-освітнього середовища: використання технологій хмарних обчислень, врахування розробниками веб-застосунків та ЕОР особливостей різних комп'ютернотехнологічних платформ та дієві механізми застосування IКТ-аутсорсингу. 
Науковці підкреслюють актуальність досліджень щодо основ використання IКТ в умовах розвитку інклюзивної освіти та забезпечення комп'ютерноорієнтованої підтримки навчання осіб з особливими потребами [1].

Аналіз наукових праць з проблеми дослідження вказує на те, що в сучасній педагогічній науці адаптивність освітнього процесу розглядають 3 точки зору використання новітніх ІКТ або врахування психофізіологічних особливостей студентів, зокрема осіб 3 інвалідністю. Спільним $\epsilon$ те, що основними характеристиками адаптивного освітнього середовища науковці вважають гнучкість освітнього процесу та його орієнтацію на індивідуальні особливості здобувачів вищої освіти.

На нашу думку, вдалим буде підхід, що грунтується на поєднанні обох точок зору, оскільки науково обгрунтоване та педагогічно доцільне впровадження в освітне середовище нових IКT, зокрема адаптивних систем навчання, дозволяє забезпечити гнучкість та індивідуалізацю освітнього процесу для всіх здобувачів вищої освіти і створити умови для рівного доступу до якісної освіти. Формування адаптивного освітнього середовища передбачає інтеграцію педагогічних, інформаційних та інклюзивних технологій, що дає можливість максимально врахувати індивідуальні здібності та потреби здобувачів вищої освіти.

Властивість адаптивності є основою формування освітнього середовища, яке відповідає запитам суспільства та вимогам забезпечення якості освіти. Реалізація цієі властивості грунтується на використанні інформаційних технологій в освітньому процесі, що створює необхідні умови для індивідуалізації та диференціації навчання з урахуванням психофізіологічних особливостей студентів.

Таким чином, під адаптивним освітнім середовищем закладу вищої освіти розуміємо цілеспрямовано побудовану інноваційну педагогічну систему в освітній діяльності, створену на основі сучасних педагогічних, інформаційнокомунікаційних та інклюзивних технологій, методів та інтеграції комп'ютерно орієнтованих засобів 3 інформаційно-ресурсним забезпеченням, призначену для адаптації сучасного освітнього процесу до можливостей і потреб здобувачів вищої освіти, в тому числі осіб з інвалідністю.

Перспективним напрямом дослідження вбачаємо проектування адаптивного освітнього середовища ЗВО на основі хмаро орієнтованих платформ і створення методики його впровадження в освітній процес.

\section{Література}

1. Биков В.Ю., Спірін О.М., Пінчук О.П., Проблеми та завдання сучасного етапу інформатизації освіти. URL : http://lib.iitta.gov.ua/709026/1/Пробл\%20та\%20завд\% 20\%20інформатизаціі\%20освіти.pdf (дата звернення: 12.02.2019).

2. Бондар Т. І. Створення інклюзивного освітнього середовища в системі вищої освіти України. Science and Education a New Dimension. Pedagogy and Psychology. Будапешт, 2014. Вип. II(14). № 27. C.77-79. URL : http://seanewdim.com/uploads/3/2/1/3/3213611/ bondar_t.i._developing_the_inclusive_setting_in_higher_education_institutions_in_ukraine.pdf (дата звернення: 20.12.2018).

3. Бояринов Д. А. Адаптивное образовательное пространство. Научное обозрение. Педагогические науки. 2015. № 1. C. $94-95$. URL : https://science-pedagogy.ru/ru/ article/view?id= 656 (дата звернення: 21.12.2018).

4. Закон України Про освіту. URL: http://zakon.rada.gov.ua/laws/show/2145-19 (дата звернення: 21.12.2018).

5. Карташова Л. А. Відкритий мережевий ресурс “Accent”: інноваційні можливості для освітян. Комп’ютер у школі та сім'ї. 2016. №5 (133). С. 3-8.

6. Карташова Л. А., Бахмат Н. В., Пліш І. В. Розвиток цифрової компетентності педагога в інформаційно-освітньому середовищі закладу загальної середньої освіти. Інформаційні 
технології і засоби навчання. 2018. Том 68. №6. URL : http://lib.iitta.gov.ua/713236/1/ Розвиток\%20цифрової\%20компететності\%20педагога\%20в\%20освітньому\%20середовищі\% 20Пліш\%20Карташова\%20Бахмат.pdf (дата звернення: 12.02.2019).

7. Кислякова Ю.Н. Особенности создания адаптивной образовательной среды в условиях инклюзивного образования. URL : http://elib.bspu.by/handle/doc/16459 (дата звернення: 15.12.2018)

8. Колупаєва А. А., Софій Н. 3., Найда Ю. М. та ін. Концептуальні аспекти інклюзивної освіти. Інклюзивна школа: особливості організації та управління: навч.-метод. посіб. Київ, 2007. 128 c.

9. Кольченко К. О., Нікуліна Г. Ф. Концептуальні підходи до впровадження інклюзивної освіти у вищих навчальних закладах. URL : http://ap.uu.edu.ua/article/38 (дата звернення: 21.01.2019).

10.Макар Л. М. Сутність освітнього середовища в педагогічному процесі. Педагогіка формування творчої особистості у вищій і загальноосвітній школах. 2013. Вип. 30 (83). C. $229-236$.

11.Носенко Ю. Г. Адаптивні системи навчання: сутність, характеристика, стан використання у вітчизняних закладах педагогічної освіти. Фізико-математична освіта. 2018. Вип. 3(17). C. $73-78$

12.Организация образовательной среды для детей с особенностями психофизического развития в условиях интегрированного обучения: учеб. - метод. пособие / С. Е. Гайдукевич, Т. А. Григорьева, Н. Н. Баль, И. В. Зыгманова, И. Н. Миненкова; под общ. ред. С. Е. Гайдукевич, В. В. Чечета. Минск : БГПУ, 2005. 98 с.

13.Пішванова В. О. Принципи адаптивного навчання. Вісник Запорізького національного університету. 2015. №1(24). С. 178-183.

14.Тлумачний словник сучасної української мови: Загальновживана лексика / за заг. ред. В. Калашника. Харків : ФОП Співак, 2009. 960 с.

15.Третьяков С.Н. Адаптивное управление педагогическими системами: учебное пособие / П. И. Третьяков, С. Н. Митин, Н. Н. Бояринцева. Москва : Академия, 2003. 368 с.

16. Федорук П. І. Адаптивна система дистанційного навчання та контролю знань на базі інтелектуальних інтернет-технологій : автореф. дис. на здобуття наук. ступеня док. тех. наук. Київ, 2009. 40 c.

17.Цюман Т. П., Бойчук Н. І. Кодекс безпечного освітнього середовища: метод. посіб. / за заг.ред. Цюман Т. П. Київ, 2018. 56 с.

18. Чайковський М. Є. Теорія і практика соціально-педагогічної роботи з молоддю з особливими потребами в умовах інклюзивного освітнього простору: дис. на здобуття наук. ступ. док. пед. наук. 13.00.05 - соціальна педагогіка. Старобільськ, 2016. 570 с.

\section{References}

1. By'kov V.Yu., Spirin O.M., Pinchuk O.P., Problemy' ta zavdannya suchasnogo etapu informaty'zaciyi osvity' URL : http://lib.iitta.gov.ua/709026/1/Probl\%20ta\%20zavd\%20\% 20informaty zaciyi\%20osvity'.pdf (data zvernennya: 12.02.2019).

2. Bondar T. I. Stvorennya inklyuzy'vnogo osvitn 'ogo seredovy'shha v sy'stemi vy'shhoyi osvity' Ukrayiny'. Science and Education a New Dimension. Pedagogy and Psychology. Budapesht, 2014. Vy'p. II(14). \# 27. S.77-79. URL : http://seanewdim.com/uploads/3/2/1/3/3213611/ bondar_t.i._developing_the_inclusive_setting_in_higher_education_institutions_in_ukraine.pdf (data zvernennya: 20.12.2018).

3. Boyary`nov D. A. Adapty'vnoe obrazovatel'noe prostranstvo. Nauchnoe obozreny`e. Pedagogy'chesky'e nauky'. 2015. \# 1. S. 94-95. URL : https://science-pedagogy.ru/ru/ article/view?id= 656 (data zvernennya: 21.12.2018).

4. Zakon Ukrayiny` Pro osvitu. URL: http://zakon.rada.gov.ua/laws/show/2145-19 (data zvernennya: 21.12.2018).

5. Kartashova L. A. Vidkry'ty`j merezhevy'j resurs "Accent”: innovacijni mozhly'vosti dlya osvityan. Komp'yuter u shkoli ta sim'yi. 2016. \#5 (133). S. 3-8.

6. Kartashova L. A., Baxmat N. V., Plish I. V. Rozvy'tok cy frovoyi kompetentnosti pedagoga v informacijno-osvitn 'omu seredovy'shhi zakladu zagal noyi seredn'oyi osvity'. Informacijni texnologiyi i zasoby' navchannya. 2018. Tom 68. \#6. URL : http.//lib.iitta.gov.ua/713236/1/ Rozvy' tok\%20cy' frovoyi $\% 20$ kompetetnosti $\% 20$ pedagoga $\% 20 \mathrm{v} \% 20$ osvitn' omu $\% 20$ seredovy' shhi $\% 20$ Plish\%20Kartashova\%20Baxmat.pdf (data zvernennya: 12.02.2019). 
7. Ky'slyakova Yu. N. Osobennosty' sozdany'ya adapty'vnoj obrazovatel'noj sredyi v uslovy'yax y'nklyuzy'vnogo obrazovany'ya. URL : http://elib.bspu.by/handle/doc/16459 (data zvernennya: 15.12.2018).

8. Kolupayeva A. A., Sofij N. Z., Najda Yu. M. ta in. Konceptual'ni aspekty' inklyuzy'vnoyi osvity'. Inklyuzy' vna shkola: osobly 'vosti organizaciyi ta upravlinnya: navch.-metod. posib. Ky' yiv, 2007. 128 c.

9. Kol'chenko K. O., Nikulina G. F. Konceptual'ni pidxody' do vprovadzhennya inklyuzy'vnoyi osvity' u vy'shy'x navchal'ny'x zakladax. URL : http://ap.uu.edu.ua/article/38 (data zvernennya: 21.01.2019).

10. Makar L. M. Sutnist' osvitn'ogo seredovy'shha v pedagogichnomu procesi. Pedagogika formuvannya tvorchoyi osoby`stosti u vy`shhij i zagal’noosvitnij shkolax. 2013. Vy’p. 30 (83). S. 229-236.

11. Nosenko Yu. G. Adapty'vni sy'stemy' navchannya: sutnist', xaraktery'sty'ka, stan vy'kory 'stannya u vitchy'znyany'x zakladax pedagogichnoyi osvity'. Fizy'ko-matematy'chna osvita. 2018. Vy'p. 3(17). S. 73-78.

12. Organy'zacy'ya obrazovatel' noj sredyi dlya detej s osobennostyamy' psy'xofy'zy' cheskogo razvy'ty'ya $v$ uslovy'yax y'ntegry' rovannogo obucheny'ya: ucheb. - metod. posoby'e / S. E. Gajdukevy'ch, T. A. Gry'gor' eva, N. N. Bal', Y'. V. Zyigmanova, Y'. N. My'nenkova; pod obshh. red. S. E. Gajdukevy'ch, V. V. Checheta. My'nsk : BGPU, 2005. 98 s.

13. Pishvanova V. O. Pry'ncy'py' adapty`vnogo navchannya. Visny'k Zaporiz'kogo nacional nogo universy'tetu. 2015. \#1(24). S. 178-183.

14. Tlumachny’j slovny'k suchasnoyi ukrayins'koyi movy': Zagal'novzhy'vana leksy'ka / za zag. red. V. Kalashny'ka. Xarkiv : FOP Spivak, 2009.960 s.

15. Tret'yakov S. N. Adapty`vnoe upravleny'e pedagogy'chesky'my' sy'stemamy': uchebnoe posoby ‘ / P. Y'. Tret' yakov, S. N. My'ty'n, N. N. Boyary`nceva. Moskva : Akademy'ya, 2003. 368 s.

16. Fedoruk P. I. Adapty'vna sy'stema dy'stancijnogo navchannya ta kontrolyu znan' na bazi intelektual'ny'x internet-texnologij : avtoref. dy's. na zdobuttya nauk. stupenya dok. tex. nauk. Ky' yiv, 2009. $40 \mathrm{~s}$.

17. Cyuman T. P., Bojchuk N. I. Kodeks bezpechnogo osvitn`ogo seredovy'shha: metod. posib. / za zag.red. Cyuman T. P. Ky'yiv, 2018. $56 \mathrm{~s}$.

18. Chajkovs'ky'j M. Ye. Teoriya i prakty'ka social'no-pedagogichnoyi roboty' $z$ moloddyu $z$ osobly'vy'my' potrebamy' v umovax inklyuzy'vnogo osvitn'ogo prostoru: dy's. na zdobuttya nauk. stup. dok. ped. nauk. 13.00.05 - social'na pedagogika. Starobil's'k, 2016. $570 \mathrm{~s}$.

Одержано статтю: 19.03.2019

Прийнято до друку: 2.04.2019

УДК $378.4(71)$

DOI: $10.15330 /$ esu. $15.25-31$

\section{Марія Клепар,}

кандидат педагогічних наук, доцент, ДВНЗ “Прикарпатського національного університету імені Василя Стефаника" (м. Івано-Франківськ, Україна)

Maria Klepar,

Candidate of Pedagogical Sciences $(\mathrm{PhD})$, Associate Professor, Vasyl Stefanyk Precarpathian National University (Ivano-Frankivsk, Ukraine)

mkleparI0@gmail.com

\section{ПРОФЕСПЙНА ПІДГОТОВКА МАЙБУТНІХ ФАХІВЦІВ-МІЖНАРОДНИКІВ: ДОСВЈД США І КАНАДИ}

\section{PROFESSIONAL TRAINING OF FUTURE SPECIALISTS-INTERNATIONALISTS: EXPERIENCE OF THE USA AND CANADA}

У статті здійснено аналіз досвіду (історія, теорія, практика) підготовки бакалаврів і магістрів міжнародних відносин у США і Канаді. Показано, ио теоретичні узагальнення з иієї проблеми спонукають корегувати національну систему професійної 